\title{
Analysis of The Characteristics And Potential of The Park's Energy Consumption Based On Typical Energy Usage Scenarios
}

\author{
Baozhong Zhou ${ }^{1}$, Dunnan $\mathrm{Liu}^{2}$, Sihan $\mathrm{Wu}^{1}$, Erfeng $\mathrm{Xu}^{3}$, Jingwen $\mathrm{Hua}^{2 *}$ \\ ${ }^{1}$ Huadian Electric Power Research Institute Co., Lt, Hangzhou, Zhejiang, 310030, China \\ ${ }^{2}$ Economics and Management Department, North China Electric Power University, Beijing, 102206, China \\ ${ }^{3}$ Zhejiang Zheneng Energy Service Co., Ltd, Hangzhou, Zhejiang, 310012, China
}

\begin{abstract}
This paper analyzes the main energy use scenarios of typical parks and studies the energy use characteristics of industrial parks, commercial complexes, and transportation hubs. By superimposing the energy consumption period and characteristics of large, medium and small users in the park, the overall energy consumption characteristics of the park and the typical load characteristics in summer and winter are studied, which helps to improve energy consumption behavior and increase energy ratio. In addition, in view of the superimposed energy consumption characteristics of the park, the article proposes two energysaving methods to help the park use the peak-valley effect to reduce energy consumption.
\end{abstract}

\section{Introduction}

The park generally refers to a standard building or building planned and constructed by the government that has complete water supply, power supply, gas supply, communications, roads, storage and other supporting facilities, reasonable layout, and can meet the needs of production and scientific experiments in a specific industry group.

Synthesize the current status of energy demand in typical parks and the actual status of energy users, and classify energy types, including energy demand for electricity, cold and heat, and natural gas. In terms of user types, the park users include large industrial users, general industrial and commercial users, residential users, and public needs. The energy demand of different types of users constitutes the overall comprehensive energy system of the park. The analysis of the overall energy use characteristics and energy potential of the park will help the park's energy load forecasting work, improve energy use behavior, and increase energy use levels. The article focuses on the analysis of energy consumption scenarios in typical parks, such as industrial parks, commercial complexes, and transportation hubs.

\section{Typical energy usage scenarios}

\subsection{Industrial park}

Generally, the industrial park covers a large area, and the total number of enterprises is large, and the main industry is relatively single. The types of users in the industrial park are mainly industrial users, and they also include certain residential buildings for the employees of the enterprises in the park to live, and there are also certain public environmental energy needs. The industrial parks are classified according to the industrial planning and layout of the parks, which are mainly divided into discrete manufacturing, process industries, and emerging R\&D industries. Through detailed analysis of the typical energy use scenarios of the three types of industrial parks, the typical energy use scenarios of general industrial parks are analyzed

\subsubsection{Discrete Manufacturing Park}

Discrete manufacturing mainly includes communication facilities, aerospace, electronic equipment, machine tools, automobiles, various types of home appliances, toy manufacturing, clothing and other industrial types. Most of its products are assembled from parts and components that have certain functions. The energy consumed is mainly the power consumed by the production and processing equipment, and mainly consumes electricity.

In addition, the heating and air-conditioning of plants in this type of industrial park often account for a large proportion of the total energy consumption. The heat-toelectricity ratio of the terminal energy demand in the northern region in winter is about 5.7; in the southern area, if the steam lithium bromide absorption refrigeration and electric refrigeration of the waste heat boiler are used at the same time, and the low-temperature waste heat is used for hot water, the heat-to-electric ratio of the energy demand will be much greater than 3 . For discrete manufacturing industrial parks, the heating methods are mainly distributed air conditioning, central heating, power plant waste heat heating, and precision air conditioning; cooling methods include distributed air conditioning, electric refrigeration units, and precision air conditioning.

\footnotetext{
a Corresponding author: huajingwen0315@163.com
} 


\subsubsection{Process Industrial Park}

The process industry includes electric power, metallurgy, chemical industry, papermaking, food, medicine and other industrial types. Its raw materials and products are generally materials or materials with specific functions and properties. In fact, in my country's industrial structure, the total energy consumption of the process industry is much greater than the total energy consumption of the discrete manufacturing industry. In the end energy consumption of the process industry, electricity accounts for a small proportion of the total energy consumption, and the ratio of heat to electricity is generally greater than 3 .

In the heat demand of the process industry, steam generally accounts for a relatively large proportion, followed by logistics heating. For different industrial processes, the temperature range of heat demand varies greatly. For example, the heat used in the building materials industry ranges from 800 to $1000^{\circ} \mathrm{C}$, while the heat used in the food industry is generally around $100^{\circ} \mathrm{C}$; the heat demand for the oil refining industry ranges from $100^{\circ} \mathrm{C}$ to $500^{\circ} \mathrm{C}$.

The temperature range of industrial refrigeration demand is also very wide, from the cryogenic demand of about $-180^{\circ} \mathrm{C}$ in the ethylene industry and air liquefaction and separation process to the general demand for shallow cooling of about $0-20^{\circ} \mathrm{C}$.

\subsubsection{Emerging R\&D Type Industrial Park}

Emerging $R \& D$ industrial parks mainly include $R \& D$ industries such as electronic information, new materials, biotechnology, energy conservation and environmental protection, and new energy. According to different types of R\&D industries, each industry has its own unique process flow and energy use scenario.

\subsection{Commercial complex}

Commercial complex is a combination of more than three functions of urban living spaces such as commerce, office, residence, hotel, exhibition, catering, conference, and entertainment in the city, and establishes an interdependent and mutually beneficial dynamic relationship between each part, Thus forming a multifunctional, efficient, complex and unified complex. Because it is mostly reflected in the relationship of interconnected buildings, the functional analysis of commercial complexes is carried out according to the architectural positioning. The main functional buildings include high-density office buildings, hotels, supporting shopping malls or commercial buildings, experience exhibition centers and general residential user buildings. The buildings produced and lived by different types of non-industrial users reflect different electricity usage scenarios and electricity usage habits.

In terms of electricity consumption, the main building groups in the commercial complex (highdensity office buildings, offices, hotels, supporting shopping malls or commercial buildings, general residential user buildings) mostly use electricity for lighting, air conditioning, power, etc., covering a large area, And electricity consumption grew steadily.

In terms of heat use, the thermal energy demand in commercial complexes mainly comes from public/domestic, centralized/decentralized heating needs. Due to the differences in regions and climates, commercial complexes in the north have centralized heating requirements, while some areas in the south have heating Demand, in most areas, electricity/electric heating for air-conditioning is used instead of heat demand.

In terms of cold utilization, the cold energy demand in commercial complexes mainly comes from the demand for air conditioning and refrigeration in summer and the demand for food preservation cold storage. Among conventional non-industrial users, centralized air conditioners consume $40-60 \%$ of electricity consumption.

In terms of gas consumption, for industrial and commercial users and residents, gas is mainly used for gas appliances, gas water heaters and some gas air conditioners.

\subsection{Transportation Hub}

China's major transportation hubs integrate ordinary railways, urban express railways, and urban rail transit in the architectural structure. There are more functional electrical equipment, and the overall electrical load is relatively large. The electrical loads of the subprojects vary.

In terms of electricity consumption, the electricity demand for transportation hubs is mainly divided into three categories: (1) Electricity demand for communications, power, and lighting. As far as large railway stations are concerned, the communication, power, lighting and other equipment in the station have high requirements for power supply. High-speed railway stations and airports also have fairly stable power loads. (2) Electricity for traffic traction. Indoor rail transit in many cities is connected to railway stations, which involves the electricity demand for traction and the electricity demand for lighting instructions. (3) Electricity for public environment. As a place with a large flow of people, transportation hubs should fully consider communications, automatic fire alarms, equipment monitoring, office power, public environment and power use for functional equipment (air conditioning, ticket collection machines, passage gates, ticket inspection areas, toilets, etc.), etc. demand.

In terms of heat use, the use of heat energy in transportation hubs is mainly reflected in centralized heating.

In terms of cold utilization, the utilization of cold energy in transportation hubs is reflected in food cold chain transportation and summer air conditioning.

In terms of gas consumption, the demand for gas in transportation hubs is reflected in gas appliances and gas water heaters that use gas as the main energy source to generate heat. 


\section{Analysis of park energy consumption characteristics}

\subsection{Analysis of energy consumption characteristics of industrial parks}

In typical energy use scenarios in industrial parks, general industrial parks are divided into three categories based on the industrial planning and layout of the park: discrete manufacturing, process industries, and emerging R\&D industries. Since the industrial processes in the parks after classification are similar, and the production characteristics are similar, the general industrial parks will be scientifically integrated within a certain space to improve the intensive intensity of industrialization, carry out industrial integration, and highlight industrial characteristics to optimize the functional layout, such as heavy industry Parks, light industrial parks, chemical parks, high-tech parks, export development zones, etc. The following will analyze the overall energy consumption characteristics of the three types of industrial parks by analyzing the types, numbers, production characteristics, and production load rates of users in the three types of industrial parks: discrete manufacturing, process industries, and emerging $R \& D$ industries.

Table 1.Energy load characteristics of discrete manufacturing and process industrial

\begin{tabular}{|c|c|}
\hline $\begin{array}{c}\text { Energy } \\
\text { type }\end{array}$ & Characteristic analysis \\
\hline \multirow{6}{*}{ Electricity } & $\begin{array}{c}\text { Electricity load presents certain fluctuations } \\
\text { and peak-to-valley characteristics during } \\
\text { the day. It is mainly from } 7 \text { am to } 9 \text { pm } \\
\text { (working hours). The load at night is low, } \\
\text { and the volatility is obvious with the } \\
\text { seasons during the year. In summer and } \\
\text { winter, the electricity load is higher. }\end{array}$ \\
\hline \multirow{6}{*}{ Cold/Heat } & $\begin{array}{c}\text { Heat and cooling loads vary with seasons } \\
\text { and regions. Industrial heat and cooling } \\
\text { loads are relatively stable and vary with } \\
\text { production shifts. In addition to the higher } \\
\text { growth in summer cooling load, } \\
\text { commercial/civilian winter heating in } \\
\text { northern regions The load is high, and the } \\
\text { southern area is mostly replaced by electric } \\
\text { energy. }\end{array}$ \\
\hline Gas & $\begin{array}{c}\text { The gas consumption load is relatively } \\
\text { stable and varies with the production shifts } \\
\text { during the day, and there are peak gas } \\
\text { consumption periods at noon and evening. }\end{array}$ \\
\hline
\end{tabular}

Table 2. Energy load characteristics of emerging R\&D industrial parks

\begin{tabular}{|c|c|}
\hline $\begin{array}{c}\text { Energy } \\
\text { type }\end{array}$ & Characteristic analysis \\
\hline & $\begin{array}{c}\text { Electricity load presents a certain degree of } \\
\text { volatility within the day. The electricity } \\
\text { load is relatively stable from 00:00 to } 8: 00, \\
\text { and it is basically industrial, computer, and } \\
\text { laboratory equipment. The industrial } \\
\text { electricity load increases from } 8: 00 \text { to } \\
\text { Electricity } \\
18: 00, \text { and the commercial Electricity load }\end{array}$ \\
\hline
\end{tabular}

\begin{tabular}{|c|c|}
\hline & $\begin{array}{l}\text { rises, and residential electricity } \\
\text { consumption has small fluctuations; from } \\
\text { 18:00 to } 24: 00 \text {, industrial electricity load } \\
\text { stabilizes. Due to the continuous nature of } \\
\text { industrial research in some enterprises, the } \\
\text { electricity consumption curve is slightly } \\
\text { higher than that of night industrial } \\
\text { electricity. Civil electricity reaches the peak } \\
\text { in the day, and there is a small peak in the } \\
\text { electricity curve at 19:00-21:00. }\end{array}$ \\
\hline Cold/Heat & $\begin{array}{l}\text { New R\&D parks generally need to control } \\
\text { the temperature and humidity of the } \\
\text { experimental environment. Therefore, the } \\
\text { new R\&D parks need to consume cold and } \\
\text { heat throughout the year and maintain } \\
\text { stable fluctuations during the year. Due to } \\
\text { heating and cooling requirements during the } \\
\text { year, it varies with seasons and regions. } \\
\text { fluctuation }\end{array}$ \\
\hline Gas & $\begin{array}{c}\text { Gas consumption load is relatively stable, } \\
\text { and there are peak gas consumption periods } \\
\text { at noon and evening }\end{array}$ \\
\hline
\end{tabular}

\subsection{Analysis of energy consumption characteristics of commercial complex}

The commercial complex is a large-scale complex that combines multiple functional buildings. The main building groups include: high-density office buildings, offices, hotels, supporting shopping malls or commercial buildings, and general residential user buildings.

Table 3.Energy load characteristics of commercial complex

\begin{tabular}{|c|c|}
\hline $\begin{array}{c}\text { Energy } \\
\text { type }\end{array}$ & Characteristic analysis \\
\hline Electricity & $\begin{array}{l}\text { Electricity load presents a certain degree of } \\
\text { volatility in the day. 0:00-6:00, the } \\
\text { electricity load is relatively low, mainly } \\
\text { responsible for the electricity demand of } \\
\text { hotels and the night power demand of office } \\
\text { buildings, offices, and businesses; } 6: 00-8: 30 \text {, } \\
\text { The power demand of supporting } \\
\text { commercial users and residential buildings } \\
\text { has increased, and the overall power } \\
\text { consumption curve is showing an upward } \\
\text { trend; from 8:30 to 18:00, the power demand } \\
\text { of commercial users, high-density office } \\
\text { buildings and government agencies reached } \\
\text { the highest and maintained a stable trend, } \\
\text { The overall electricity load is relatively high } \\
\text { and the electricity consumption curve is } \\
\text { relatively stable. The peak load fluctuations } \\
\text { appear between 10:30-12:30; } 18: 00-22: 30 \text {. } \\
\text { The demand for high-density office } \\
\text { buildings and government offices decreases, } \\
\text { and the demand for residential electricity } \\
\text { increases, The electricity demand of the } \\
\text { mall fluctuates, and the total electricity load } \\
\text { drops; } 22: 30-24: 00 \text {, the demand for } \\
\text { supporting commercial users' electricity } \\
\text { drops sharply, the residential electricity load } \\
\text { has a certain drop, and the total electricity } \\
\text { load drops. The average annual electricity } \\
\text { load of the commercial complex is relatively } \\
\text { stable, with obvious fluctuations in summer } \\
\text { and winter. }\end{array}$ \\
\hline
\end{tabular}




\begin{tabular}{|c|c|}
\hline & $\begin{array}{c}\text { The energy load curves of heat energy, cold } \\
\text { energy, and natural gas mainly vary with } \\
\text { user demands. During the day, due to the } \\
\text { continuous fresh-keeping of refrigerators and } \\
\text { cold storage, domestic cooking utensils, and } \\
\text { water heaters, the cooling load curve is } \\
\text { relatively stable, and the heating and air } \\
\text { Gas } \\
\text { supply load curves fluctuate during meal } \\
\text { periods and night. In terms of geographical } \\
\text { and seasonal dimensions, the heat load } \\
\text { increases sharply in winter (especially in the } \\
\text { northern regions), and the demand for } \\
\text { cooling load is greater in summer. }\end{array}$ \\
\hline
\end{tabular}

\subsection{Analysis of energy consumption characteristics of transportation hub}

Because of the uninterrupted operation of the transportation hub area and providing passengers with a comfortable and convenient waiting and riding environment, the energy consumption of public facilities and commercial energy accounts for most of the total energy consumption. The energy load in the transportation hub area is mainly for lighting, communication, office, and power energy. There are corresponding needs in supporting commerce, roads and transportation, public facilities, and railway/track. Comprehensive analysis of the energy consumption characteristics of the transportation hub area is as follows:

Table 4.Energy load characteristics of transportation hub

\begin{tabular}{|c|c|}
\hline Energy type & Characteristic analysis \\
\hline Electricity & $\begin{array}{l}\text { Because the transportation hub area is a } 24 \mathrm{~h} \\
\text { service area, the average daily electricity } \\
\text { load is relatively stable, of which lighting } \\
\text { electricity, power electricity, and } \\
\text { commercial electricity account for a large } \\
\text { part, but because tourists tend to travel } \\
\text { during the day and send high-speed } \\
\text { rail/train/aircraft at night There are fewer } \\
\text { shifts, so the average electricity load is } \\
\text { higher from 7:00 to 23:00, reaching the } \\
\text { peak of electricity consumption during the } \\
\text { peak period of people flow. In addition, the } \\
\text { electricity load in the transportation hub } \\
\text { area exhibits obvious seasonality and } \\
\text { periodicity. During general holidays and } \\
\text { important holidays, the electricity load in } \\
\text { the transportation hub increases greatly } \\
\text { compared to working days. In summer and } \\
\text { winter, it is Meet the needs of } \\
\text { environmental heating, cooling, domestic } \\
\text { hot water supply, etc., and the electricity } \\
\text { load also has a greater increase compared } \\
\text { with the spring and autumn. }\end{array}$ \\
\hline Cold/Heat & $\begin{array}{l}\text { The transportation hub area also needs to } \\
\text { meet the passengers' demand for public } \\
\text { environment and cold and heat energy. } \\
\text { First, there is a demand for refrigeration in } \\
\text { passengers, supporting businesses, and } \\
\text { public facilities. The supporting } \\
\text { commercial storage of food also requires } \\
\text { cold storage to help keep it fresh. The } \\
\text { railway/aircraft catering cold chain also has }\end{array}$ \\
\hline
\end{tabular}

\begin{tabular}{|c|c|}
\hline & $\begin{array}{c}\text { cold energy demand. Therefore, the annual } \\
\text { cooling load is relatively stable, which is } \\
\text { obvious in summer. increase. Second, heat } \\
\text { energy is generally used to meet } \\
\text { environmental heating, domestic hot water } \\
\text { supply and other needs, and these needs are } \\
\text { supplied in real time due to service needs. } \\
\text { Therefore, the heat load in the } \\
\text { transportation hub area is relatively stable } \\
\text { throughout the year, with a significant } \\
\text { increase in winter. }\end{array}$ \\
\hline Gas & $\begin{array}{c}\text { The gas demand is mainly for commercial } \\
\text { gas, gas-fired heaters, etc., and the gas load } \\
\text { is high from 7:00 to 23:00 in the day. }\end{array}$ \\
\hline
\end{tabular}

\section{ANALYSIS OF PARK ENERGY SAVING POTENTIAL}

The overall energy-saving potential analysis of the park focuses more on the energy-saving potential shown after the superposition of all users' energy consumption. According to the user's energy consumption and response characteristics, realize the adjustment and redistribution of the energy consumption of the park users in the time dimension, forming a complementary effect similar to "shifting peaks" between users, thereby reducing the overall energy consumption of the park and improving the overall park Energy efficiency.

\subsection{Differentiated time-of-use price mechanism}

Peak-to-valley time-of-use electricity prices can effectively guide users to rationally use electricity and adjust system load through price signals. Reasonable time-of-use electricity prices can allow park users to actively change electricity consumption, so as to achieve the purpose of peak cutting and valley filling. As users are more and more sensitive to the time-of-use price, different types of power users have different responses to the time-of-use price. Therefore, it is necessary to develop a differentiated time-of-use price mechanism to analyze the impact of different types of power users on the time-of-use price. Response characteristics, according to their respective characteristics, establish a reasonable time-of-use electricity price adjustment mechanism.

\subsection{Energy demand side response}

Large-scale parks and energy-using areas have different requirements in time and space for multiple energy sources such as cold, heat, and electricity. The production capacity/energy consumption characteristics, supply and demand characteristics of different energy subsystems are quite different. The coupling mechanism in the time and space of multi-energy flow can be used to realize multi-energy complementation. Therefore, when users change their demand for one or more energy sources, the supply and demand relationship of another energy source will be affected. Demand response is an effective means to integrate the response potential of the energy grid on the user side of the park. Users can adjust 
the demand of different energy sources through the demand response mechanism to achieve the same effect of peak shaving and valley filling, alleviating energy tension, and realizing the integration of multiple users Demand response to achieve the energy-saving goals of the park.

\section{Acknowledgment}

This paper is supported by project named " Research on Key Technologies and Operation Modes of Comprehensive Energy Services Adapting to the New Environment of Power Market ".

\section{References}

1. YANG Jingw ei, ZHANG Ning, WANG Yi, et al, $\mathrm{M}$ ulti-energy system towards renew able energy accommodation: Review and prospect [J]. Automation of Electric Pow er Systems, 42(2018)

2. DENG Lirong, SUN Hongbin, CHEN Runze, et al . Research onnodal energy price of combined heat and pow er system for energy internet $[\mathrm{J}]$ power System Technology, 40 (2016)

3. ZENG Ming, LIU Yingxin, ZHOU Pengcheng, et al . Review andprospects of integrated energy system modeling and benefit evaluation $[\mathrm{J}]$. Power System Technology, 42 (6):1697-1708. (2018)

4. ZHANG Shixiang, L Shuaikang. Evaluation method of park-level integrated energy system for microgrid [J]. Pow er System Technology, 42 (8): 2431-2439. (2018)

5. CHEN Baisen, LIAO Qingfen, LIU Dichen, et al. Comprehensive evaluation indices and methods for regional integrated energy system [J]. Automation of Electric Power Systems,42 (4): 174-182 (2018)

6. NAVEED Q N, QURESHI M R N, ALSAYED A O, et al. Prioritizing barriers of E-learning for effective teaching-learning using fuzzy analytic hierarchy process (FAHP) [C]/ / 2017 4th IEEE International Conference on Engineering Technologies and Applied Sciences (ICETAS). Salmabad: IEEE (2017)

7. GOYAL R.K, KAUSHAL S. Deriving crisp and consistent priorities for fuzzy AHP-based multicriteria systems using non-linearconstrained optimization [J]. Fuzzy Optimization and Decision M aking, 17(2): 195-209 (2018)

8. LIU Si, FU Xuhua, YE Chengjin, et al. Spatial load distribution based on clustering analysis and nonparametric kernel density estimation [J]. Power System Technology, 41(2) :604-609 (2017) 